\title{
Фимип Ивановић*
}

\section{Уводник}

На вијест о смрти митрополита црногорско-приморског Ар Амфилохија Радовића, редакција нашега часописа одлучила је да пети број за 2021. годину садржи и посебну секцију посвећену његовој успомени. Ава су примарна разцога за такву одлуку: прво, митрополит Амфимохије, као Ааровити и образовани теолог, оставио је Аубок траг у духовном животу Црне Горе, али и дао изузетан научно-истраживачки допринос на поьима патристике, библистике, црквене историје и уопште теологије, те тако завријеАио мјесто међународно уваженог научног радника; друго, он је, оА самога почетка, пратио и подржавао раА Центра за хеленске студије и био јеАан оА покровитеља његових активности, међу којима су оснивање Akropolis-a 2017. године и одржавање Прве међународне конференције хеленских студија у Херцег Новом 2019. године. Стога, текстови сабрани у овом броју представљају скромни омаж научнику, чији су истраживачки и образовни путеви били умногоме везани за Византију и савремену Грчку, али и добротвору, који је разумио значај познавања и изучавања хеленскога свијета за културни и цивилизацијски развој једног модерног Аруштва.

Модерно Аруштво и модерни човјек, са својим потребама, страховима, надама и манама, инспирација су митрополитовога научног ангажмана, који он, сигурно не случајно, усмјерава на ad fontes, конкретно на византијску патристичку мисао, која на својесвсртан начин представьа прожимање античке грчке филозофије, културе и језика са хришћанском вјером. Рођен три године прије почетка Аругог свјетског рата у Југосмавији и посвједочивши страхотама највеће трагедије човјечанства XX вијека, млади Ристо Радовић ће се 1950-их година упутити у БеограА, како би завршио богословску школу и касније студирао теологију, упоредо изучавајући античке језике и књижев-

\footnotetext{
* Центар за хеленске студије \& Универзитет Аоња Горица, Црна Гора (fivanovic@helenskestudije.me)
} 
ност на студијама кцасичне филологије. Биле су то године обнове разорене Европе, али и почетка ХАадног рата и све већег утицаја француског егзистенцијализма, сартровског и камијевског типа. Све то је несумњиво оставило трага на младог богослова, који се, након Београда, упућује у Берн и Рим на постАипломске студије, Аа би се коначно обрео у Атини с намјером Аа отпочне раА на докторској тези о Григорију Пахами, ${ }^{1}$ јеАном оА најутицајнијих византијских богослова и мислилаца. Није неоправдано претпоставити да су искуства рата и послијератних дешавања, уз боравак у европским метрополама у којима су Сартрова чувена теза „Аруги су пакао“ и Камијева реинтерпретација грчкога мита о Сизифу у смислу испразности ьудске егзистенције, допринијела Радовићевом избору Аа, као круну свог истраживачког рада, одабере Григорија Паламу, не само као теолошког ауторитета, већ и мислиоца чије „цјелокупно богословско созерцање ... јесте превасходно антрополошко“, оАносно кога „стално занимају Авије ствари: човјек и јеАина његова нада“.2

Не прихватајући поменуту максиму Аа су Аруги пакао, а дубоко свјестан Аа је „освајање спољних простора“ у ствари једностраност која је „проузроковала отућење човјека од његових унутарњих простора “, 3 Радовић позива на преиспитивање таквог антрополошког песимизма:

Патолошка немоћ општења с Аругим, Аа би оправдала себе, проглашава Аругог за кривца, па бимо Аа је тај Аруги Бог или човјек. Но тамо гаје ишчезне Аик Аругога неминован је сусрет с ништавимом: херојско историјско остваривање себе у ствари је бјекство оА своје болесне немоћи и тог и таквог ништавила и то, по правилу, бјекство ка нечему Аругом као спасењу. Бунтовно самољубње, глад за предметима, опсесија робом, новцем и похотом - све то што је толико присутно у животу савременог човјека, у суштини није ништа Аруго до унакажени оАсјај искања Аругога, жеђи за њим. ${ }^{4}$

\footnotetext{
${ }^{1}$ Ова теза једна је од најбољих теолошких књига написаних на грчком језику у XX вијеку. У неАавно објављеној књизи о Григорију Палами, Радовићева теза се наводи као „major point of reference for Orthodox studies on the Trinity“, те се Аање каже да је митрополитово разматрање размика̂ суштине и енергије „the most lucid exposition of Palamas> thinking on the topic to date in a modern language“. (Russell, Gregory Palamas, 122-121.)

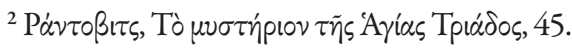

${ }^{3}$ Амфилохије, „Исихазам“, 76.

${ }^{4}$ Амфилохије, „Аитургија и подвижништво“, 58.
} 
Овај релациони карактер човјека, као обиьежје хришћанске онтологије, Радовић узима „као темеь постојања човјека као мичности“.5 Аругим ријечима, „неАруштвен човјек, то јест човјек без Аругог, није човјек“. ${ }^{6}$ Већ на први поглед овај став не евоцира само хришћанску афирмацију зајеАнице, већ и формом и суштином подсјећа на Аристотелово одређење човјека

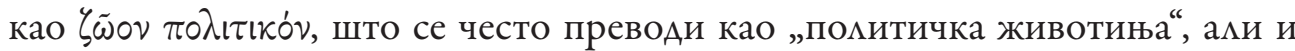
као „Аруштвено биће“, у смислу Аа „онај тко се не може зАруживати или му ништа не треба због самодостатности ( $\alpha \dot{\tau} \tau \dot{\alpha}$ ркєı), тај и није никакав дио граАа, те је или звијер или бог“" Аруштвеност човјека, односно његова ремационост, као потреба за удруживањем, тј. за животом у зајеАници, доживјела

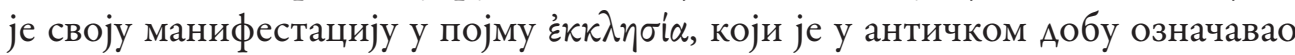
скупштину грађана демократских градова-Аржава, Аа би у хришћанској терминологији задобио значење саборне зајеАнице ими - цркве.

Та потреба за Аруштвеношћу, односно за остваривањем смислених релација човјека са Аругим, како год то схватили, у аристотеловском или у хришћанском смиску, обиьежје је савременога човјека, који свагда трага за начинима Аа своју ремационост оствари:

Може бити да ниједна Аруга епоха није тако изразито засвједочила ту дубинску глаА за општењем као што то чини наша епоха. Та глаА најбове долази до изражаја кроз савремену технику, кроз устројство савременог града и Аруштва. Колоније хипика, совјетски колхози и израелски кибуци, ницање свуда по свијету религиозних група, као и такозвано „Подруштвљавање“ преАмета производње, те револуционарно уништавање милиона јединки ради „колективног“ добра; искање хьеба за све и похоте као хьеба пуноће и ситости - све је то мице и наличје трагичног немира чији је ковитлац ухватио обескоријењеног човјека нашег доба. ${ }^{8}$

Свијест о потреби за заједничарењем, тј. оштењем, човјека са својим бцижњим, овАје очигмеАно није прости резултат богословског теоретисања, одвојеног оА реацнога свијета, већ је производ темеьног разумијевања актуелнога филозофског промишьања, мичнога искуственог испитивања и, можда најважније, Аубоког саосјећања с егзистенцијалним потребама савре-

\footnotetext{
${ }^{5}$ Кнежевић, „ОА келије до агоре“, хіі.

${ }^{6}$ Амфимохије, „Суочавање божанске и ьудске егзистенције“, 24.

${ }^{7}$ Arist., Pol., $1253 \mathrm{a}$.

${ }^{8}$ Амфикохије, „Аитургија и подвижништво“, 59-58.
} 
менога човјека. Није стога ни чудо што Амфимохије управо таквог, савременог и тјескобом оптерећеног, човјека ставља у центар свога промишљања, аристотеловски аргументујући његову Аруштвеност, сократовски афирмишући његово самоспознање и хришћански свједочећи да се заједница човјека са човјеком и човјека с Богом пројавьује „као ништа Аруго до пуноћа историјски и реално доживљене ьудске свакидашњице, пуноћа у којој ниједна ьудска суза не може бити изгубьена или заборавьена“?

Амфилохијево упозорење да је човјек „по својој природи дубљи и шири оА космоса у коме пребива, отуда је и његова глаА за дубином и ширином незаситива Аубинама и ширинама ове материјалне стварности “10 у ствари је позив на испитивање „унутарњих простора“, на интроспекцију, оАносно на преиспитивање себе и свога живота, у смислу Сократовога Аиктума Aа „неиспитан живот није вријеАан живњења“. или опитовање Паламино своди се на акумулацију душевних сила тако Аа се човјек „ослобађа оА свог страственог односа према себи и свијету“. ${ }^{12}$ Но, не подсјећа ми ослобађање оА страствених односа на Сократово схватање филозофије као припреме за смрт ${ }^{13}$ Та филозофија не подразумијева неко некрофилно радовање ништавилу нити позив на самоубиство, већ преАставља управо ослобађање оА страсти, у смислу Аа онај који се боји смрти није sубитем мудрости, него ьубитеь тијема. ${ }^{14}$

Постаје јасна, Аакме, Амфилохијева филозофска и теолошка антропологија из наведених фрагмената, који за циь имају наговор на изучавање његових увиАа, а који могу поскужити као примјер непрекинуте мисаоно-искуствене нити, оА античке филозофије, преко византијског богословља, Ао емпиријски утврђене свакидашњице савременога човјека. Претходни се екскурсус, дакце, може сматрати непотпуним и фрагментарним покушајем разумијевања $\mathrm{Pa}$ Аовићевог односа према стању човјека његовога времена и потреби да се то стање саглеАа у свјетлу класичних, грчко-византијских, јеАнако хуманистичких и хришћанских, парадигми, чија је актуелност и у XXI вијеку још јасније изражена у контексту све већег, објективним околностима наметнутог и себеьубњем потврђеног, отуђења човјека од Аругога и себе самога.

\footnotetext{
${ }^{9}$ Ibid., 75.

${ }^{10}$ Амфимохије, „Исихазам“, 76.

${ }^{11} \mathrm{Pl} .$, Apol., 38a.

${ }^{12}$ Амфимохије, „Исихазам“, 82.

${ }^{13}$ Pl., Phaed., 67e.

${ }^{14}$ Ibid., 68b.
} 
Стога текстове који слиједе треба прихватити не само као омаж међународно признатом научнику, вишедеценијском архипастиру и великодушном добротвору, већ и као подстицај на дање разрађивање круцијалних теолошких, филозофских, психолошких, Аингвистичких, културолошких и историјских питања, оА значаја за судбину човјечанства:

Тражи ми вјечну пуноћу своје мичности у ономе што је нема само по себи (а то су човјек и природа узети сами за себе, условьени својом тварношћу и промјеньивпшћу), значи да пристаје на коначно ништавимо себе и својих односа, то јест на смрт. Открива $и$ иични однос са вјечним Аругим, кроз своје општење са њим, и кроз свој непоновьиви начин постојања у односу на природну општост и исто тако непоновьиву разцичитост других бића, човјек тиме открива словесност (Аогосност) своју и свега постојећег. ${ }^{15}$

Овај специјални број отвара се текстом Костаса Атанасопулоса (Отворени универзитет, УК), који испитује поглеАе митрополита Амфилохија на мисао Григорија Паламе у контексту савременог православьа, нарочито се фокусирајући на његову докторску тезу, одбрањену 1973. године у Атини. Аутор закьучује Аа су одређени проблеми православља, идентификовани још 70-их година прошлога вијека, још увијек актуелни, те Аа њихово разрјешавање може бити потпомогнуто дубьим познавањем Пацамине мисле, на чему је и Радовић инсистирао.

ВАадимир Цветковић (Универзитет у Београду) на детањан и исцрпан начин испитује утицај Јустина Поповића на митрополита Амфимохија, нарочито у контексту његових раних екуменистичких поглеАа, који су често били преАмет супротстављених интерпретација. У раду се истичу сличности Радовићевих и Поповићевих погледа, али и њихова размичита тумачења истог феномена.

Енрико Морини, с Универзитета у Болоњи, бавио се, у свом раду, ауторитетом канона̂ у контексту оснивања Московске патријаршије, конкретно на Сабору у Цариграду 1593. године и Сабору у Москви 1917. године. Аутор показује како се Ава кьучна бесједника на овим саборима, наиме алексанАријски патријарх Мелетије Пигас у Цариграду и Икарион Троицки у Москви, позивају на исте црквене каноне, али из размичитих перспектива̂ - док се Пигасово тумачење односи на универзалну цркву и редосьед патријараш-

\footnotetext{
${ }^{15}$ Амфимохије, „Суочавање божанске и ьудске егзистенције“, 24.
} 
ких тронова, дотме се Иларион ослања на исте каноне, али са цињем очувања црквене аутономије на нивоу мокалне јурисдикције.

Примог Аушана Крцуновића (Универзитет Црне Горе) анахизира концепт „новога човјека“ апостола Павла и контрапонира га савременој идеји трансхуманизма, као релативно новом виђењу ьудскога прогреса. У кьучу хришћанске антропологије и Павлове формуле, аутор контрастира апостоцово разумијевање динамике ьудског живота са трансхуманистичким појмом „човјековог побоьшања“ (buman enhancement) уз помоћ технологије.

На крају, Петер Женух и Светлана Шашерина (САовачка академија наука) анализирају комуникативну функцију језика у конкретном контексту старих словенских превода библијских и митургијских текстова. Аутори тврде Аа је исправно разумијевање тих текстова засновано не само на тачној употреби конкретних термина, већ и на вјеродостојном опису реалности, што је и била једна оА полазних тачака за преводилачку активност Солунске браће. 


\section{Aumepamypa}

Амфимохије, митрополит, „Исихазам као освајање унутарњих простора“, у: Id., Пламен божествени у ништавом храму, избор и предговор Микоња Кнежевић, БеограА: Српска књижевна задруга, 2021, 76-87.

Амфимохије, митрополит, „Аитургија и подвижништво“, у: Id., Пламен божествени у ништавом храму, избор и предговор Микоња Кнежевић, БеограА: Српска књижевна задруга, 2021, 56-75.

Амфилохије, митрополит, „Суочавање божанске и ьудске егзистенције“, у: Id., Пламен божествени у ништавом храму, избор и предговор Микоња Кнежевић, БеограА: Српска књижевна задруга, 2021, 22-34.

Aristotle, Politica, ed. W.D. Ross, Oxford: Clarendon Press, 1957

Aristotel, Politika, pr. Tomislav Ladan, Zagreb: Globus, 1988

Кнежевић, Микоња, „ОА келије до агоре“, у: Митрополит Амфилохије, Пламен божествени у ништавом храму, избор и предговор Микоња Кнежевић, Београд: Српска књижевна задруга, 2021, vii-xvii.

Plato, Platonis opera, ed. J. Burnet, Oxford: Oxford University Press, 1903

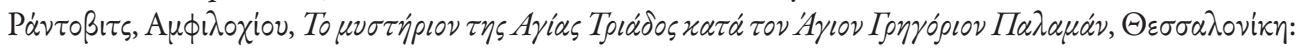

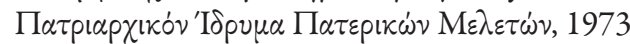

Russell, Norman, Gregory Palamas and the Making of Palamism in the Modern Age, Oxford: Oxford University Press, 2019 